\title{
7 \\ The Modern Mysticism of Taha Abderrahmane
}

\author{
Harald Viersen
}

\section{Introduction}

Over the last forty-odd years Taha Abderrahmane has produced a vast oeuvre in which he interweaves modern logical methods and philosophy of language with a deep knowledge of the Islamic intellectual heritage to produce a philosophy for the modern Muslim and his society. An important thread that runs throughout his writings is his Sufi orientation. Since at least the publication of his book Religious Practice and the Renewal of Reason (al-Amal al-Dìni waTajdid al-Aql), in 1989, Abderrahmane has made it clear that he views the (re-)appreciation of its mystical heritage as central to the renewal of Islamic society. Sufi practice, he argues, is fundamental to a particular way of viewing the world, a particular reason (' $a q l$ ). The form of reason associated with Sufism Abderrahmane dubs 'supported reason' (al-'aql al-mu'ayyad). This most perfect form is distinguished from two other forms of reason, namely 'abstracted reason' (al-'aqlal-mujarrad), which he associates with Western modernity, and 'guided reason' (al-'aqlal-musaddad), which is associated with Islamic practice insofar as it is not guided by Sufi principles. This three-tiered structure returns in later works, such as The Renewal of Method in the Reevaluation of Heritage (Tajdìd al-Manhajfi Taqwìm al-Turāth), The Question of Ethics: A Contribution to the Ethical Critique of Western Modernity (Su'äl al-Akhlāq: Musāhama fìal-Naqd al-Akhlāqi lil-Hadātha al-Gharbiyya) and The Spirit of Modernity: The Portal to the Establishment of Islamic Modernity (Rūḥ al-Hadātha: al-Madkhal ilā Ta'sīs al-Hadātha al-Islāmiyya).

As is the case for all his writings, Abderrahmane's command of Sufi heritage and his knowledge of Sufi texts is thorough. His acquaintance with Sufi discourse is, moreover, amplified by his personal involvement in its practice. He does not use Suf literature only as a source of inspiration for his own writings, or as a way of providing an authentic Islamic license for a modern philosophical project. His intellectual relation to Sufism is clearly rooted in lived mystical experience. ${ }^{1}$

1 The first edition of The Religious Practice included an introduction in which Abderrahmane discusses the role of Sufism in his life. This section was left out in subsequent editions. (See: Mashrūḥ 2009, 33, n. 1).

(C) HARALD VIERSEN, 2020 | DOI:10.1163/9789004438354_010

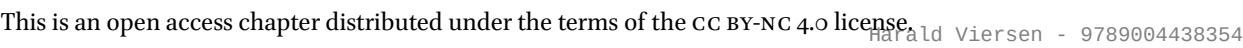


Notwithstanding the classical Sufi spirit of his writings, Taha Abderrahmane remains a philosopher whose life straddles the turn of this millennium. He may refer to al-Ghazālī (d. 505/1111), Ibn 'Arabī (d. 638/1240), or al-Qushayrī (d. 465/1073), but the kinds of questions that he faces are not those faced by a philosopher at the court of Nizām al-Mulk (d. 485/1092) in 11th century Baghdad. This, it should be stressed, is no mere triviality. As the British intellectual historian Robin George Collingwood reminds us, questions are as important in understanding a thinker as his answers to these questions. "A body of knowledge", he writes, "consists not of "propositions," "statements," or "judgments," but of these together with the questions they are meant to answer ... a logic in which the answers are attended to and the questions neglected is a false logic" (Collingwood 1939, 36-37).

Taking this insight to heart, we ought to treat Abderrahmane's philosophy in light of the distinctly modern questions that animate it: the confrontation between different cultures and value systems, critical reflection on philosophical translation, the tenets of Western modernity, the refutation of Salafism and the politicization of Islam, and the formulation of an alternative, Islamic modernity. All of these problems belong to a modern context. Even if one were to point out that concerns about correct philosophical translation or the confrontation between value systems are not limited to our age, it is undeniable that they have become more central to a modern consciousness. Questions of identity, authenticity, and intercultural relations take on a distinct character in the modern world. They are treated differently in a technologically advanced age, in which people are on the one hand more often confronted with different ways of viewing the world, while on the other hand they experience the pervasive universal influence of Western ideas as a rival to local views and practices.

Approaching Abderrahmane's writings from the side of the questions that he is trying to answer will, in the first place, shed new light on his intricately fashioned philosophical system. However, it will accomplish more than this. For one, putting his work in a modern context is crucial to understanding his increasing popularity among a modern readership. Sufism has gained popular appeal in both Eastern and Western societies and several of the most prominent Arab intellectuals of the 2oth century have turned to Sufism as a source of inspiration for a modern philosophy. Looking at how Abderrahmane and other modern philosophers have used Sufism to shape their thinking will enable us to better understand what it is that modern readers find in Sufism that helps them cope with the exigencies of modern life.

Finally, one should keep in mind that even though the direct aims of this chapter are narrowly exegetical, its effect will likely exceed these bounds. 
Sufism is central to Abderrahmane's entire philosophical project. By redefining the role that Sufism plays within this system, the entire epistemological and ontological apparatus that underlies his philosophy will have to move along with it. In particular, it will be argued that the role of the individual and his relation to society are greatly affected by the more individualistic modern context in which Sufism is employed. A detailed examination of how this ought to influence our perception of Abderrahmane's ethical positions lies beyond the purview of this article, but that it ought to play a significant role in our assessment of his theory of ethics lies beyond doubt.

Abderrahmane's Sufism

Taha Abderrahmane's interest and involvement in Sufi practice dates back to his youth, when his father introduced him to a local sheikh ('Abd al-Rahmān 2017, 9.00 min). He is known to follow the Budshishiyya order and has talked in some detail about the influence that Sufism has had on his life and thought (Bătțawī 2013). This influence is palpable in his writing, both in its structure and its content. One could point, for instance, to the way he uses the triliteral structure of the Arabic words to conceive of different interrelated terms stemming from the same roots and ascribing a special, immanent meaning to these relations. It is evident also in his fondness for inventing tripartite classifications to define mystical states, ${ }^{2}$ in his idiosyncratic vocabulary and in his references to Suf learning and poetry. ${ }^{3}$

In terms of the content of his philosophical project, Abderrahmane's Sufi orientation leaves its mark on his analysis of reason. For Abderrahmane the analysis of reason has been a central preoccupation from the very start of his career as a philosopher. ${ }^{4}$ Already in his doctoral thesis, written at the Sorbonne, we see a young thinker interested in explaining how a culturally spe-

2 This is characteristic of Sufi literature (Schimmel 1975, 13).

3 For example, Abderrahmane's creative, idiosyncratic and therefore much-discussed translation of the Cartesian cogito with unzur tajid carries a distinct Sufi flavor as it stems from a poem ascribed to the 13th century Andalusian Sufi Abū al-'Abbās al-Mursī. (The entire hemistich reads "look and find in you existence in its entirety" - unzur tajid fika al-wujūd bi-asrihi.) In an interview, Abderrahmane indicated that he found this line referenced in a work by Ibn 'Ajība, but only after having come up with this translation himself ('Abd al-Raḥmān 2013a, 77-78). The title of the book referenced in a footnote as the source of Abderrahmane's find, namely Ibn 'Ajība's Taqyīdān fi Wahdat al-Wujüd, does not contain the name of the author of this line. It is another book by Ibn 'Ajïba that ultimately refers us to Abū al-'Abbās al-Mursī (Ibn 'Ajïba 20o6, 295).

4 On several occasions Abderrahmane has recalled that he was spurred to study what he terms the West's "reason" ( $a q l$ ) following the Arab defeat in the Six Day War of 1967 in an effort to 
cific reason is formed by language (Abderrahmane 1979). In his later books, starting with The Religious Practice and The Renewal of Reason (al-Amal al-Din̄i wa-Tajdìd al-'Aql), published in 1989, he goes further and establishes a hierarchy between different kinds of reason. This book is Abderrahmane's first attempt at articulating an alternative to two distinct ways of viewing the world: that of the West and of modern non-/anti-Sufi Islam. As alluded to above, Abderrahmane associates each of these with a particular form of reason and then goes on to propose a third kind that encompasses the other two, yet also goes beyond them in important ways, fixing what is wrong with both.

According to the framework presented in The Religious Practice, reason is not a single, stable entity, but a continuous activity that has different stages of development. Abderrahmane follows Sufi doctrine by describing these different stages as steps in a single journey. One ascends through the different forms of reason, starting at the lowest rungs of the ladder and climbing ever higher with the aim of attaining a perfect form of understanding. The most basic stage is defined by Abderrahmane as that of abstracted reason. Abstracted reason refers to the kind of demonstrative reason that he thinks is typical of Western culture. It portrays reason as a faculty, present in each human being, the sole purpose of which is to relate ideas and impressions to each other. This is essentially the kind of reason associated with empirical science. It takes the appearances at face value, as an indication of the ultimate nature of reality and tries to give a true and exhaustive description of this reality. ${ }^{5}$

Abstracted reason offers a limited perspective on the world, according to Abderrahmane. Try as it might, it cannot go beyond the limits of what is given in experience. Importantly, it lacks any moral dimension. In the Western imagination, man has become the measure of all things. Western philosophers have severed the link between ethics and religion, ${ }^{6}$ thereby removing any limits to man's practical engagement with the world, leaving it entirely up to his whims how he decides to act. As consciousness of the deeper, meaningful dimension of nature recedes, the world is turned into a sterile place that is only knowable insofar as its goings-on can be brought under scientific laws. Given this outlook, only that remains valuable which serves the needs of man. The empirical sciences that are based on the use of abstracted reason may increase his ability to predict and manipulate nature, but he is left without any purpose outside of his own arbitrary will.

find out how to counter Western dominance of the Muslim world ('Abd al-Rahmān 2013, 17; 'Abd al-Raḥmān 2017, 17.30 min).

5 For a definition of abstracted reason, see: 'Abd al-Rahmmān 2009, 17.

6 See his more recent work for a thorough analysis of this phenomenon ('Abd al-Rahmmān 2014). 
The concept of abstracted reason serves as the starting point for Abderrahmane's critique of Western modernity. In fact, one may discern in Abderrahmane's portrayal of the effects of abstracted reason a basically Weberian analysis of the modern predicament. When he describes the Western outlook as without value or meaning, he essentially refers to what Max Weber (18641920) has described as the gradual process of disenchantment characteristic of Western modernity. Like Weber, Abderrahmane considers this a sorry state of affairs. He goes further, however. According to him, abstracted reason goes against the essential nature of mankind. Man is essentially, he says, an ethical creature. What distinguishes him from animals is not his capacity for reason, but his ability to engage in ethical practice ('Abd al-Raḥmān 2013, 147). Modern Western man has become ignorant of this fact. He has put (abstracted) reason on a pedestal, forgetting about his moral duties. This is the source of the ills of modernity that he discusses more in his later, full-fledged critiques of Western modernity (Ibid., 76).

One step up from abstracted reason is guided reason (al-'aql al-musaddad). The main difference between this form of reason and abstracted reason is that it focuses on practice, not on theory. In following the rules contained in the divinely revealed law, it leads man towards happiness and away from harm. ${ }^{7}$ Thus, in contrast to abstracted reason, which aims to provide a picture of what the world is like, it guides man according to a divinely sanctioned moral framework. Guided reason does not go against the essence of man, because it acknowledges the central role that practice plays for a being whose essence it is to be ethical.

Acknowledging the practical dimension of human life, guided reason has some clear advantages over abstracted reason. It relates our actions to values (qiyam), instead of merely to our personal goals (ghāyāt). By turning towards eternal values, man enters a realm of meaning. The sterile environs of abstracted reason get imbued with value, independent of man's particular predilections. Guided reason serves as a bridge that leads man beyond the limits of appearances, showing him the contours of the moral framework that undergirds Creation.

Yet, guided reason also has some defects, or ills (āfāt) as Abderrahmane refers to them. Living according to the rules set by the revealed law does not necessarily require any insight into their rationale or deeper meaning. It only requires that one abide by the superficial meaning of these rules, which

7 See for the formal definition: 'Abd al-Raḥmān 2oog, $5^{8}$. 
may cause people to perform their religious duties in the wrong way and for the wrong purpose. This defect of superficiality (âfat al-tazāhur) may cause believers to put in only the most minimal effort necessary to comply with Sharia, instead of dedicating one's whole life to the worship of Allah. It may induce them to be more interested in impressing other people with their devotion, either deserved or undeserved. Or, by contrast, they may become overly concerned with their own actions and disregard the other, as well as God's role in enabling them to perform these actions ('Abd al-Rahmmān 2009, 7983).

Moreover, guided reason can lead to believers merely imitating others, instead of judging for themselves what is demanded of them-which Abderrahmane calls âfat al-taqlìd, or "the defect of mimicry" ('Abd al-Rahmān 20o9, $83-89$ ). This is not cured by a return to the original texts, as is presumed by adherents of Salafism. Salafis may rely less on the example of others, but their readings of these texts are essentially of an abstracted kind ('Abd al-Rahmān 2009, 99-100), as they pay no heed to the spiritual side of Islam. Moreover, their approach to Islam is liable to lead to politicization (tasyis) and extremism (tatarruf), as was demonstrated by the sometimes violent politicization of Islam that has affected the Middle East in particular from more or less the $1970 \mathrm{~s}$ until this day. ${ }^{8}$

If abstracted reason is associated with Western modernity and guided reason with the Islamic revival (al-șahwwa al-islämiyya) that occurred during the second half of the 2oth century, then the third type of reason discussed by Abderrahmane is that of Sufi practice and it presents a correction to both. ${ }^{9}$ It therefore presents the final stage of development; reason in its complete, perfect form. This reason, which he dubs 'supported,' inquires into the essence of things through engaging in the practice of divine law and going beyond the necessary requirements of this law. ${ }^{10}$ By engaging in the kind of spiritual practice associated with supported reason, man not only inquires into the outer appearance of how the world is - as is the case with abstracted reason, nor does he try to determine the right kinds of actions in light of the revealed law-as with

8 It should be remembered that many strands within Salafism have demonstrated a particularly fierce animosity towards Sufism. Abderrahmane's specific defense of Sufism against Salafi opponents should be understood within this context (Knysh 2017, chap. 6).

9 Abderrahmane explicitly positions his work as an alternative both to Western reason and the șaḥwa in the introduction to al-'Amal al-Dīnīwa-Tajdìd al-'Aql ('Abd al-Raḥmān 2009, 9).

$10 \quad$ Ibid., 121. 
guided reason. Rather, with spiritual practice man adopts a new view on the world around him that allows him to perceive the inner essence of what surrounds him. He who commits to this practical experience (al-tajriba al-hayya ${ }^{11}$ ) realizes that the truth addresses him in every thing he encounters, in himself and in all of God's creations and that all of this is suffused with a meaningful dimension dependent on Him ('Abd al-Rahmmān 2009, 128). The practitioner moves from a mere superficial ( $z \bar{a} h i r)$ following of the rules set by the revealed law, to an understanding of their hidden (ba âtin) meanings. The moral demands placed on the believer are enlivened. Rather than being abstract dos and don'ts they turn into aesthetic values that he can experience directly in nature ('Abd al-Raḥmān 2013c, 88-89). Faith is thus turned from an ascetic duty into a continuous, pleasurable experience of how all God's creatures relate to Him ('Abd al-Raḥmān 2013a, 19-20).

This intimate acquaintance with the essential structure of nature has important ethical consequences. To understand why, we need to realize that Abderrahmane does not see actions as discrete events that allow for only one kind of description. Actions can be performed in many different ways. They have different dimensions, depending on the context as well as on the person who performs the action ('Abd al-Raḥmān 2013c, 81-84). Changes in these aspects change the character of the action and it is only through a process of constantly attuning oneself to new situations that man learns to be a perfect ethical being.

This is precisely the point at which supported reason goes beyond guided reason. Whereas both subscribe to rules laid down in the Sharia, guided reason merely follows the letter while the supported reason implements these general rules according to the specific personal demands of each situation. Echoing similar arguments made by Western philosophers like Charles Taylor (b. 1931), Paul Ricoeur (1913-2005), and Alasdair Macintyre (b. 1929), ${ }^{12}$ Abderrahmane stresses that ethics is not to be conceived of as a system of commandments, but as a way of being in which your actions are consonant with your personality. One should not judge acts individually, but as part of a narrative that defines someone's personality ( $\mathrm{fa}$-takūn akhlāq al-insān hiya qișsatuh allatī tuhaddid huwiyyatah, 'Abd al-Rahmān 2013c, 157). Consequently, the question of what one ought to do-the question of ethics—cannot be decided on a general

11 In Abderrahmane's rather idiosyncratic vocabulary the term hayy, which would normally be translated as "alive," is defined in opposition to theoretical (nazarī) and conceptual (tașawwurī), as meaning practical (Ibid., 122, n. 41).

12 Abderrahmane in fact refers to Macintyre and Ricoeur in making this point (Abderrahmane 2013C, 157, n. 21). 
basis. It differs for each person and is particular to someone's personality and the particular situation that he is in. Supported reason is, essentially, a process in which man attunes himself to the changing flow of the world (taghayyur) and to the changing states of his own self.

More than a correction of the non-Sufi practice of Islam, supported reason offers a position from which to criticize and correct the ills that beset the modern world. If the central problem of modernity is the way in which it rids nature of all meaning, in other words its disenchantment, then Abderrahmane's appeal to supported reason can be read as a form of reenchantment. Through Sufi practice, he claims, man learns to discern what is hidden behind the surface of experience, which in turn allows him to reconnect to values that inhere in nature and are not derivative of man's personal desires. Where the modern condition is characterized by a lack of certainty ('adam al-yaqin) and of quietude ('adam al-itminān) supported reason alleviates this deep-felt anxiety by taking away its root causes, namely man's estrangement from nature, ethics, and religion ('Abd al-Raḥmān 2009, 223).

Abderrahmane is by no means the only contemporary Arab intellectual to have turned to Sufism for inspiration in confronting the modern world. Having given a brief outline of the role that Sufism plays in his philosophy we will take a detour to see how other contemporary Arab intellectuals have benefited from Sufi learning to defend the concept of the modern individual. The aim of this comparison is to show, by way of examples, how Sufism has been used to shape their ideas; what kinds of questions these writers try to answer and why Sufism in particular has appealed to them as a traditional basis for a modern philosophical outlook.

To be clear, this comparison is not meant as an assessment of who is more in line with the Sufi tradition. The aim is to show how modern uses of Sufism exhibit certain affinities, due to the fact that they are articulated within a shared modern context. Far from being a stable, coherent set of teachings, the Sufi tradition is vibrant, ever-changing, and often inconsistent. Despite at times very vigorous opposition, it has survived through the centuries by adapting to new circumstances, spreading the world over and fusing with local traditions. Rather than try to pinpoint a supposedly orthodox Sufism in order to judge whether moderns are following this orthodox line or corrupting it, it is more fruitful to regard modern intellectuals who articulate new interpretations of Sufism as continuing the process of re-articulation and adaption. They too 
bring out certain aspects within the Sufi tradition, while obscuring others in response to questions that matter to them.

Naturally, considering their shared environment, modern receptions of Sufism reveal certain general trends. For example, Alexander Knysh notes that "Sufism's modern-day advocates have tended to minimize or even deny its association with such "objectionable" beliefs and practices," like "grave worship" and "popular superstitions." Moreover, modern interpretations of Sufism tend to emphasize the individual aspects of mystical practice. In order to appeal to modern sensitivities, "Sufism has become subtly "privatized"." As part of this process of elevating Sufism above the level of the quotidian, more philosophically minded interpreters have come to "foreground its gnoseological and metaphysical aspects," expanding the notion of Sufism to include falsafa (Knysh 2017, 47-48).

Privatization and intellectualization are, indeed, two aspects of the modernday, philosophical receptions of Sufism that will be discussed here, namely those of Abdurrahman Badawi and Adonis. For both of them, Sufism offers resources to analyze and critique what they see as a deficient mode of being in modern society. In response to the superficial, positivistic worldview they associate with modernity, they tout a new philosophy of life, centered on the individual. Their reception of Sufi insight reflects this orientation, as their interpretations of some of its central doctrines emphasize the central role of the individual as a source of value in an otherwise meaningless world.

\subsection{Abdurrahman Badawi}

Abdurrahman Badawi (1917-2002) is widely considered to be the father of existentialism, if not of modern philosophy, in the Arab world. His $\mathrm{PhD}$ defense in 1944 at the University of Cairo was a "national event" that was covered in the national media. None other than Taha Husayn (1889-1973) hailed it as "the birth of modern Arab philosophy" (Di-Capua 2018, 52). Badawi's exposure to existentialism started under the tutelage of the French phenomenologist Alexandre Koyré (1892-1964). During the latter's stint at the University of Cairo, which started in 1933, he introduced his students to the works of Edmund Husserl (1859-1938) and Martin Heidegger (1889-1976). Upon being introduced to this new and exciting branch of philosophy, Badawi became convinced that Heidegger's existentialist philosophy was the way of the future. Being Koyré's most promising student, he set himself the ambitious task of founding an Arab existentialism that could function as the philosophical framework for a modern Arab society.

Badawi is too intelligent and creative a thinker to be pinned down as a mere copyist and interpreter of European existentialist philosophy. He has made ser- 
ious efforts to further develop existentialist thought. So confident was he of his own ability to take existentialism to a higher plane that he describes his work as complimentary to that of Heidegger (Di-Capua, 272, n. 30). Nonetheless, the kernel of his philosophical project is the French existentialist tradition and its introduction to the Arab world. One major question for someone who, like Badawi, was also steeped in the Arab philosophical, theological, and legal tradition, was how to weave existentialism together with Arab culture in a way that would give it its own, authentically Arab character. Here, Badawi turned to Sufism. Already as a student, Koyré had prodded him to explore the link between existentialism and Sufism. His philosophical project during the next decades would be to merge these two strands, Sufism and existentialism, in order to create an Arab existentialism, rooted in the local tradition.

To a large extent, this project of merging existentialism and Sufism consisted in finding equivalent terms and ideas in Sufi and existentialist philosophy. An excellent example of this is a talk he gave in Lebanon entitled al-Insāniyya wa-l-Wujūdiyya fì al-Fikr al-Arabī. In this talk Badawi starts out from the observation that both Sufism and existentialism are rooted in subjective existence (al-wujūd al-dhātī). In both cases, the different states in which the individual subject may find himself are the foundation for the general categories of existence. Both therefore subscribe to the existentialist adage that existence comes before essence (Badawi 1982, 73). Sufism, like existentialism, is a form of analysis of subjective existence. The only real existing entity is the subject. The outer world is only derivative of this subjective existence (Ibid., 74). In light of their shared starting point, it should not come as a surprise that Sufism and existentialism share a number of central ideas. Badawi's purpose in this paper is to flesh these out. He explains, for instance, that the notion of the perfect man (al-insān al-kāmil) resembles Søren Kierkegaard's (1813-1855) notion of the unique or One (Ibid., 75), that the Arabic term for ego (äniyya) - central to existentialist thought - is of Sufi origin (Ibid., 8o), and that Heidegger's notion of Angst resembles the Sufi idea of qalaq (Ibid., 88).

Through these equivalences, Badawi aims to demonstrate that Sufis have, much earlier, explored problems similar to those that concern modern-day existentialists. This then offers a way for gaining a sense of cultural authenticity. In the eyes of Badawi's generation, the faithful transmission of European ideas and styles had lasted long enough. Now was the time for Arabs to find a distinctive voice of their own. As he writes in an early work, with the revealing title 'The interests of the youth' (humüm al-shabāb): "This time our role is to be creators and not representatives, transmitters and guardians of (someone else's light)" (Di-Capua 2018, 50). 
Still, one may ask, if the Arab youth is interested in being "creators" instead of "transmitters," then why not do away with existentialism? As long as existentialist thought remains the leitmotif of modern Arab philosophy, it may be hard to lay claim to it as a specifically Arab frame of thought. The answer is, of course, that Badawi's primary allegiance is to existentialism, not Sufism. For him, Sufism is "the starting point for our Arab existentialist school that we would like to make our new philosophy for life and existence" (Badawi 1982, 99). The goal is "to furnish the existentialist school with roots (ușūl) from our spiritual history" (Ibid., 100).

In short, the interest in cultural authenticity is trumped by the substantive appeal of existentialism. This is fair enough, of course, but what was it that gave existentialism such appeal to Badawi? First of all, it must be recalled that existentialism presents a forceful rejection of a previous generation of philosophers. French existentialism arose as young French intellectuals became enthralled by phenomenology and the existentialist writings of Heidegger, partly, because it offered a way of going beyond the neo-Kantian positivism and Bergsonian spiritualism that had dominated French thought until the 1930 (Kleinberg 2005, $5^{-8)}$. In this sense, the interests of the new French that turned to existentialism dovetailed with those of Badawi and the flourishing Arab existentialist movement. The latter, too, were at odds with the kind of positivist, Cartesianism, represented by Ṭaha Husayn as well as the more Anglophile empiricism propagated by someone like Ahmad Amīn (1886-1954). However, they shared a distaste for outdated mystical thinking and rigid traditionalism. The new generation to which Badawi belonged was looking for a third option.

It is not only for contrarian reasons, however, that existentialism appealed to someone like Badawi. Particularly in its French (Sartrean) formulation, to which Badawi tends, existentialism propagates a radical notion of freedom. Instead of viewing man in terms of his background, he is viewed as a creature always at liberty to change his life and himself. This ability to wrest oneself free from the identity and circumstances that one has been saddled with explains part of the appeal to intellectuals in the (previously) colonized part of the world. As Yoav Di-Capua notes, the turn from a view of man in terms of fixed racial and cultural categories to one in which man made his own identity "from the perspective of the colonized [...] announced the possibility of being human in the universal sense of the word" (Di-Capua 2018, 9). The propagation of the self-reliant individual, moreover, has shown itself to be a powerful rallying cry in opposition to the kind of all-powerful state that continued to rule most of these countries, even after their erstwhile colonizers had left.

However, important as anticolonialism may have been to the intellectual context in Egypt during the 1940's, it would be wrong to read the appeal of 
existentialism merely through the lens of a burgeoning anti-colonial movement. Existentialism presents a powerful quintessentially modern outlook in its own right. It embodies a 2oth century restatement of the romanticist disillusionment with the Enlightenment ideals of rationality, universalism, and progress. In a modern world in which "God, Reason, Society, Improvement and the Soul are being quietly carted off," in which "the individual is more genuinely frightened and alone," existentialism offers a solution (Murdoch 1997, 223). The emphasis it places on the individual, self-reliance, and private conscience presents an antidote to the meaninglessness that besets modern man. Aware of the absurdity of life in a world that has lost meaning, the existentialist presents us with a new kind of subject, one that makes his own meaning in life by committing himself to a way of living it that is particular to him. He, in a sense, follows the individualistic orientation of modern Western thought to its logical conclusion, raising the individual to become the fountain of all value.

When we turn to Badawi's dissertation, it is this central thrust of existentialist thought that stands out. His aim here is to distinguish two ways of being: that of the self $(d h \bar{a} t)$ and of the object $\left(m a w d \bar{u}^{c}\right)$. The former is the authentic (așill) way of being for humans and it is characterized in the first place by utter freedom. The object, on the other hand, behaves according to deterministic rules that are described using what Badawi calls logical reason (al-aql al-mantiqü). Ethics ought to be determined by the tension between these two ways of being, the free and the determined, and cannot be the preserve of logical reason. Therefore, logical reason cannot be "the only faculty that man is able to use to understand the reality of living being" (Badawi 1973, 148-149).

In light of this philosophical outlook, it is clear why Badawi turned to Sufism for support. An alternative to sterile determinism, emphasis on individual experience, and the conclusion that logical reason alone cannot reveal all of what matters to human beings, a kernel of all these ideas can be found in some way or other within the Sufi tradition. Turning to Adonis, we will see that similar elements attracted him to Sufism, even though he uses them differently.

\subsection{Adonis}

Though not himself a Sufi, the well-known Syrian-Arab poet Adonis, born as Ali Ahmad Said Esber (b. 1930), has drawn inspiration from the Sufi tradition in formulating his own revolutionary, aesthetic, and humanist outlook. Adonis comes to Sufism from a poetic angle and his appreciation of it remains of a rather aesthetic kind. He views Sufis, for instance, as the forerunners of prose poetry, a form of poetry that he has championed since the 1950's as a modern alternative to the regimented classical style. According to him, prose poetry allows for the expression of important truths that neither regular speech 
nor highly stylized and regimented classical poetry is able to convey. This was acknowledged long ago by Sufi poets, who used it to give expression to mystically induced insights in forms that go beyond socially accepted schemas.

A similarly aesthetic and anti-conventional bent is evident in Adonis's perception of Sufism as a forerunner of surrealism. Like the surrealists, Sufis look on "existence as something mysterious" (Adonis 2013, 44) rather than as a world of the logical contradictions that "constitute the apparel of social conservatism" (Ibid., 73). Sufi aesthetic sense "rests on contradictions" (Ibid. 120) and it is these contradictions that push the artist to go continuously forward, to renew himself constantly using figurative language. God, according to Sufis, is not an entity distinct from existence, but is part of this world. He is a "continuous mystery" and therefore to know him requires "continuous revelation" of a symbolic, aesthetic kind (Ibid., 119). Like the surrealists, Sufis regard imagination as carrying man beyond the realm of logical consistency, beyond "material or natural reality" (Ibid., 134). Both reject the modern scientific treatment of "existence as a problem that must have a solution" that is deduced through reason and logic and aims at "exerting control over existence" (Ibid., 44). They rather look to the unconscious as offering a route to truth. "The states of Sufism," according to Adonis, "do not actually depend on proof but on seeing and taste and occur when a person is not conscious" (Ibid., 106). In Adonis's view of Sufism, it is the delirium produced by the experience of divine love that allows man to experience true reality.

As is the case for Badawi's existentialist Sufism, Adonisian Sufism is highly individualistic. It encourages the individual to look for truth through personal experience (tajriba shakhșiyya) (Adūnīs 2016a, 137). Instead of searching for truth outside of himself, the Suf "becomes the source of knowledge" (Adūnīs $2016 \mathrm{~b}, 108$ ). This quest for individuality and the need to break with conventions, to constantly renew oneself, to quarrel with the powers that be, in order to get at the truth and strive for justice, is where we see another strand in Adonis's thought rear its head, namely his advocacy for revolution. He views Sufis as not only breaking with "traditional aestheticism" (Adonis 2013, 16) but also as forming a subversive answer to the rigid laws of mainstream Islamic society. Sufism is presented by Adonis as a bastion of freethinking, inspired by a small group of creative individuals who thrived on going against the grain. Noting the aversion to Sufism of thinkers like Ibn Taymiyya (d. 728/1328) and al-Shāfi'i (d. 204/820), whom Adonis associates with traditionalist, conservative Islam, he interprets their disparagement as a form of praise. Somewhat ironically, he therefore agrees with Ibn Taymiyya's assessment that "Sufism is worshipping God without following orders or laws" (Ibid. 15). 


\subsection{Some Remarks on Badawi and Adonis}

Clearly, Adonis is attracted to some of the same features of Sufism that Badawi brought out in his existentialist reading of Sufi heritage. Both espouse a decidedly humanist Sufism in which the individual takes pride of place. Whether it is Adonis's artistic genius, or Badawi's self-reliant, authentic subject, the individual is the original locus of rights, values, and freedom. Moreover, their Sufism is highly secularized. Its Islamic pedigree is acknowledged, but the values and ideas they distill from it have a universal, non-religious claim. This is apparent in the parallels they draw between Sufism and existentialism and surrealism, respectively. They approach Sufism as a holistic philosophy of life. In their eyes it forms a more or less coherent, metaphysically substantiated worldview. Even where they may flirt with its 'irrational' sides - Adonis is particularly fond of this - the intention is not to advocate forms of magic or anything else that would fly in the face of a scientific worldview. Rather, the irrational is celebrated in its romantic guise as that which lies beyond the realm of science, that which is not discursive and which can only be "derived from experience/taste" and finds its sole expression in art.

For the most part, these cursory observations confirm the points made by Knysh about modern-day receptions of Sufism. Its private dimension is emphasized at the expense of its public manifestations. Its coherent metaphysical underpinnings are brought out to give it an air of philosophy, while its inconsistencies and anti-scientific aspects are pushed aside. Yet, their similarities go deeper than a mere playing into modern secular and scientific sensibilities. There is a more fundamental reason why these two authors turn to Sufism. They clearly subscribe to a form of humanist individualism and they see this embodied in Sufism. Their humanism, however, is not that of the 16 th century confidence in the independent use of human reason. Nor is it the kind of secular humanism that arose as a neutralizer of religious conflict in Europe one century later. Their individualism, rather, is forced upon them. It is born out of the Romantic anxiety that - in an ever more rationalized world, in which all happenings tend to be reduced to fundamental physics, in which governments grow increasingly powerful, and globalizing forces crowd out local identitiesman's link to nature, to meaning, to God has become unhinged. In order to continue to feel at home in the world, the modern individual requires a new way of relating to it.

Iris Murdoch (1919-1999) has observed that 2oth century literature produced two kinds of novels that rise to the task of fulfilling this demand: the existentialist and the mystical novel. The former, she writes, "shows us freedom and virtue as the assertion of will." It presents the reader with a figure with the "lonely brave man," someone who is deeply critical of society, a godless adven- 
turer (Murdoch 1997, 225). This character epitomizes the kind of individualism that is the "natural mode of being of the capitalist era" (Ibid., 224). Capitalism, modern science, and democracy require an ethic that sees man as an individual who moves freely and makes his own decisions, an ethic reflected in the Protestant picture of man as being endowed with a free conscience, not enslaved to authority. ${ }^{13}$ This picture of a free individual did not in itself imply a form of existential anxiety, that is, not as long as his trust in God, Reason, and Society was maintained. It was only during the 19th century, when his confidence in these father figures of the Enlightenment began to slacken, that the modern individual was confronted with the fact that the only thing he could fall back on for comfort was the curious entity put at the center of modern society: himself. Modern man now "finds his religious and metaphysical background so impoverished that he is in some danger of being left with nothing of inherent value except will-power itself" (Ibid., 224).

The mystical novel finds itself confronted with a similar kind of anxiety, but it seeks a different solution to it. Instead of grappling with an individual who might do anything, the mystical novel "shows us freedom and virtue as understanding, or obedience to the Good." Man is pictured as divided "between a fallen nature and a spiritual world" (Murdoch 1997, 225). The mystic has lost his confidence in the traditional structures of religion, but does not want to let go of religion as an idea. Mystics are also individuals, but not in the sense that they are radically free to do whatever they want. Rather, they are free to invent their own religious imagery. They are, more often than not, artists.

Although these labels are not a neat fit with either Badawi or Adonissuch broad categorizations hardly ever are-Murdoch's categorization offers us an interesting way of tracing their philosophical projects. Both are concerned about the position of man in the modern world. They fret about the relationship between the individual and an overpowering force, whether in the concrete form of an oppressive government, or the more ephemeral garb of a world without moral bearings. In response to this anxiety, both turn towards the individual.

Their different orientations are reflected in their views on Sufism. Yet, whereas Sufism, for Badawi, is a tradition that has committed itself to understanding man's existential condition and emphasizing his freedom, for Adonis, it is not only an analytical tool, but also a source of inspiration. He views mystical experience as akin to the kind of aesthetic experience that opens up new vistas of

13 For a more detailed description of the origins of modern individualism see: Taylor 1991, chap. II; Guignon 2004, chap. 3; Taylor 1989, pt. II; Macintyre 2013, chap. 3. 
what lies beyond the materialistic universe. It opens up a world of meaning that man ought to explore in endlessly creative ways. Murdoch describes the mystic as someone wanting "to invent new religious imagery (or twist old religious imagery) in an empty situation" (Ibid. 226). As a description of Adonis's ambition as a poet this is quite accurate.

The flipside of their shared focus on the individual is a deeply felt anxiety, particularly pronounced in Adonis's account, about the equalizing power of society. The individual human being is oppressed by the power of the majority. Tradition, which functions as a tool to suppress the revolutionary sentiment, is used to prohibit innovation and outlaw anyone who dares to express his individual nature and do things differently.

It is not hard to see why modern intellectuals would turn to Sufism. Islamic mysticism has a history of exploring the internal human experience. Moreover, one can see why its ascetic, solipsistic strands would lend themselves to a defense of the private sphere against the generalizing tendencies of the public. Within the Islamic tradition, Sufism is eminently suited for articulating the kind of individualistic worldviews espoused by Badawi and Adonis using a classical vocabulary.

This, however, should not mislead us into thinking that these intellectuals present no more than a restatement of ancient insight into the nature of the self. It may be, as Talal Asad (b. 1932) argues, a "mistaken assumption that modernity introduced subjective interiority into Islam." But it would equally be a mistake to deduce from this that modern receptions do not add anything new to the Sufi idea of the individual subject. Modernity does, after all, introduce "a new kind of subjectivity, one that is appropriate to ethical autonomy and aesthetic self-invention-a concept of "the subject" that has a new grammar" (Asad 2003, 225).

This, indeed, is what we see in Badawi and Adonis. In their thinking, the self-fashioning individual takes pride of place. He becomes the locus of meaning in a disenchanted world. Sufism, with its appeal to the non-materialistic, non-scientific dimensions of human experience, fits this project. It presents a tradition, internal to Islam, that appears to support more recent critiques of modernity. In reading Sufism from this point of view, its vocabulary is redefined to fit a particular idea of the individual. From a tradition that teaches "that one's ultimate fulfillment lies in transcending one's self," Sufism on these modern readings is recast so as to undergird "a new relation to the ground of one's being” (Loutfy and Berguno 2005, 152). 


\subsection{Comparing Abderrahmane with Badawi and Adonis}

At first blush, it would seem a long shot to find any convergence between Abderrahmane and two intellectuals who differ as much from him as Badawi and Adonis. They represent the very things that Abderrahmane is against. Since the earliest publication he has explicitly opposed the Badawi's existentialist philosophy as an unwarranted introduction of ontological thinking to the Arab tradition (Abderrahmane 1979, 172). Meanwhile, Adonis's radically secular worldview is hardly likely to count on Abderrahmane's endorsement.

Some clear points of contention stand out. Obviously, Abderrahmane's philosophy does not evince the same humanist orientation. He views humanism as an ideology, rooted in abstracted reason, that severs the link between ethics and religion. It puts man instead of God at the center of creation and thereby licenses him to do with the world as he sees fit. His idea of 'supported reason' is meant as an antidote to such presumptuousness. It allows man to become aware of the meaning that suffuses all of creation and how each and every one of its creatures has its own rightful place in it and thereby transforms man from a ruler in his own right to a viceroy for God on earth. This conceptualization of man's role as God's 'trustee' is central to Abderrahmane's ethical project, which has been summarized by Mohammed Hashas in terms of the 'trusteeship paradigm' (Hashas 2015, 102).

For this reason, Abderrahmane's Sufi outlook is also self-consciously religious. The kind of mystical experience that he describes is only possible within a religious (and specifically an Islamic) framework. Supported reason, after all, is the final stage within a progressive development of reason that includes the observance of the rules laid down by the Sharia. This is not the case for Badawi, who views the existentialist insight of Sufism as equivalent to that of a Christian thinker like Kierkegaard, and certainly not for Adonis, who on many occasions has given vent to his dislike for any form of organized religion.

Because Abderrahmane views Sufism as a practice rooted in Sharia he is also not interested in finding equivalences between Sufism and modern intellectual movements, like existentialism or surrealism. The kind of mystical experience achieved in Islam is of a very special kind. It is not merely one instantiation of an insight into the human condition that can be achieved through different means. Relatedly, he also puts greater emphasis on Sufi practice. Where Badawi and Adonis emphasize the philosophical and perhaps the artistic side of Sufism, they are not very much concerned with the relationship between its more abstract worldview and the observance of either Sharia or of practices associated particularly with Sufism. What it comes down to is that Badawi and Adonis approach Sufism from the outside, as intellectuals with a philosoph- 
ical project. Abderrahmane, however, approaches Sufism from the inside, as a practitioner who is convinced that its teachings hold the key to unlocking man's moral essence.

Notwithstanding their differences, there is one crucial thread that runs through and motivates all of the modern interpretations of Sufism discussed here. Whether in the existentialist appeal to the radical freedom of the individual person, or the ability of the poetic genius to find meaning outside the sterile confines of scientific discourse, or the Sufi path to experience the hidden essence of God's creation, each has turned to Sufism as an antidote to what they perceive to be the nefarious effects wrought on Arab society by Western modernity and by an overly rigid, impersonal interpretation of Islam. Existentialism is, as noted earlier by Murdoch, "the child of the Romantic movement." It both squares with the individualist ethic of a capitalist, democratic society and at the same time it offers a defense against the anti-individualistic tendencies of the bureaucratic state and the deterministic claims of modern science. Similarly, Adonis's aesthetic-secular mysticism stresses the role of the individual as a bastion against the positivistic generality proclaimed by scientists and the oppressive force of both the state and the masses. Both are critical of modernity in a way that is reminiscent of Abderrahmane, who chides the abstracted reason for causing the kind of juridification and bureaucratization that characterizes modern society, ${ }^{14}$ as well as the marginalization of human values due to the dominance of what he terms the "techno-scientific order" (al-nizāam al'ilmī al-tiqnī) (Ibid. chap. 6).

This critical stance vis-à-vis the excesses of modernity also underlies a shared fascination with Sufi attempts at articulating what lies beyond logic. When Badawi critiques the sole reliance on "logical reason" found in many Western thinkers, or when Adonis rejects Western technology/progress (tiqniyya/taqaddum), because it is incapable of going beyond the bounds of the empirical, of what is visible on the outside (zāhir), they follow in the footsteps of a Romantic tradition of modernity critique. In doing so, neither of them is very far off from Abderrahmane's fundamental criticism of Western society that has made the quest for the spiritual subservient to that of material progress, and that the modern man requires a way of reconnecting with what lies beyond empirical reality ('Abd al-Rahmmān 2014, 17). For example, when Adonis avers that, while the East may lack this technology, it has pre-

14 See the section on the modern defect of ossification (äfat al-tajmìd) ('Abd al-Raḥmān 2013c, 78-79). 
served a conception of what lies beyond appearances (bäțin) (Adūnīs 2014, 283), he is quite in tune with a central line of argument in Abderrahmane's works.

Despite the common aversion to the excesses of modernity, none of these thinkers wants to abolish it altogether. Theirs is not an illogical, anti-rational critique, but a corrective model for an alternative modernity. None of them is persuaded by a worldview that clearly opposes modern science. Badawi and Adonis both want to make room for the non-rational to function side by side with what Badawi calls logical reason. As to Abderrahmane, he is at pains to demonstrate that supported reason is not an alternative to logical reason, but instead represents the most rational form of reason ('Abd al-Rahmān 20o9, 223). This would appear to confirm the tendency among modern interpreters of Sufism to downplay the magical strands in the Sufi tradition in favor of presenting it as a holistic philosophy of life.

Their rejection of the magical does not mean, however, that these writers have ruled out any form of worldly enchantment. Harking back to the category of the modern mystic introduced by Iris Murdoch, the projects of Abderrahmane and Adonis can, in their own particular way, be described as projects of reenchantment. As radically opposed as they may be on many points, their basic intuition is the same. They see a modern world, devoid of meaning, which they wish to enliven, one through his art, the other through mystical practice. ${ }^{15}$

A further question is whether the fact that Abderrahmane shares a target with Badawi and Adonis similarly affects the way he confronts the challenge of modernity. We have seen that Badawi and Adonis, in their own way, give voice to a modern subjectivity that Talal Asad judges to be "appropriate to ethical autonomy and aesthetic self-invention." In addition, this new, individualistic ethic could be understood as connected to the modern condition, since it provides a new basis for ethics in a disenchanted world that is mainly governed by institutions that favor individualism. The question is whether this is also the case for Abderrahamne. Do we find a similar form of ethical autonomy and aesthetic self-invention in his philosophy?

At first glance, it would seem obvious that this question should be answered in the negative. If anything, Abderrahmane's main arguments are targeted at individualistic conceptions of ethics. He argues forcefully against the kind of

15 It is perhaps not entirely coincidental that Abderrahmane's first ambition was to become a poet. He views poetry as the vehicle par excellence for conveying what cannot be expressed in regular speech. 
individualism ( fardāniyya) typical of Western modernity. He claims, furthermore, that this is not a necessary component of modernity and that we should therefore try to conceive of an alternative form that does not depend on this idea ('Abd al-Rahmān 2013b, 62). Society should not be built on the abstracted individual, but proceed from the fact that people are all connected to each other as human beings under one God. For similar reasons, he has been critical of the sheer idea that one should think of one's action as being one's own and not ultimately dependent on the will of God, as this is apt to cause an undue regard for the self and contempt for the other ('Abd al-Raḥmān 2009, 82-83).

Moreover, Abderrahmane's ethics is anchored in Sharia. Unlike Badawi or Adonis, who hail the individual as the modern fount of value, he is adamant in his claim that any ethics should start from Scripture. Putting it in the strongest possible terms, he claims that "there is no religion without ethics and no ethics without religion" ('Abd al-Raḥmān 2013c, 52). Being so intimately connected to religion, it would seem that this leaves little room for fashioning a personal ethic.

Yet, there is also another side to Abderrahmane's philosophy, one that is more personal and, in its own way, emphasizes the role of the individual. The spiritual journey he proposes is centered on the self. Attunement with nature is gained through knowing yourself, your states, and how they relate to both Scripture and the particular situation in which you find yourself at any given moment. In contrast, the genuinely impersonal ethic is represented by guided reason. The mainstream modern practice of Islam is deficient, according to Abderrahmane, because it does not spare any room for a personal connection that binds man to God.

One may, of course, point out that this personal dimension is hardly new to Sufism. From the very start it has represented a strand within Islam that was focused on establishing a stronger, more personal bond between the believer and the Divine. Considered in this light, what is so very new or especially modern about Abderrahmane's approach to Islam?

Following Collingwood's logic of question-and-answer, one of the things that this paper has tried to show is that, in assessing Abderrahmane, we need to take into account what he says - the answers - together with why he says it - the questions. Especially when looking at how an author self-consciously relates to a particular tradition, we cannot content ourselves with pointing out isolated resemblances, because these resemblances only make sense within a particular context. Sure enough, Sufism lends itself to modern articulations of individualism. The reason for this is that this tradition has grappled with a pervasive, age-old philosophical problem. Man is a conscious being, endowed with a body that moves and acts in a world of objects and other beings that are (presum- 
ably) similarly conscious of their own existence. This basic condition throws up innumerable questions, which Buddhist monks, Sufi sheikhs, and 21st century cognitive scientists have all tried to answer in their own way. The mere fact that they have all grappled with similar problems, however, does not mean that the questions that they have posed and the answers that they have given are entirely commensurable. The kind of question you ask will always depend on your background assumptions. The context that gave rise to questions about the self a thousand years ago is unlike the one that governs the imagination of contemporary scientists, intellectuals, or artists. As we saw, Badawi and Adonis both turned to Sufi texts, but the views that they distilled from them had a decidedly modern ring to them, because they use old ideas to answer new questions.

Similarly, we should acknowledge the different role that the individual plays within a philosophy like Abderrahmane's. The Suf's stated goal of getting closer to Allah may not have changed very much, but the impetus for this mystical journey in a modern context is different and much more urgent. The mystical path is now meant to fend off the encroaching meaninglessness that besets modern man. Given the exigencies of modern life, which make it harder and harder for Muslims to lead a virtuous life, the need for the more exacting practice and the qualitatively deeper religious experience offered by Sufism has become greater ('Abd al-Raḥmān 2009, 154-155). As a consequence, the mystic's path is no longer optional, but necessary. Without it, society is likely to fall into the kind of moral void associated with the West or the submissive and superficial obeisance that Abderrahmane sees in the modern-day practice of Islam.

This central fact influences the character of Abderrahmane's appeal to Sufism. The self is no longer a sphere for spiritual exploration and ethical training, but a necessary link in a process that brings out the meaningful structure inherent in nature. Value may not be dependent on him in the sense of being constructed by him - as would be the case for the existentialist. However, nature is dependent on human reason for it to be recognized. Only humans are essentially ethical beings. Only a human being who has developed his aesthetic sense through worship of God is able to recognize value in nature and take care of it as befits a worthy trustee.

The indispensability of the Sufi path, moreover, implies a democratization of Sufism. No longer can Sufism be thought of as merely a strand within Islam. It is now the only way in which one can practice Islam in its true form. By implication, it cannot be the preserve of an elite. It must be open to all. Together with its democratization, Sufi practice in this context acquires a more mundane focus. The goal is no longer merely to put man at ease in this world, or to reach 
beatitude in the next. Once Sufism is used to argue for an alternative modernity, it becomes a tool for social critique as well as a source of inspiration for social improvement. Abderrahmane's trusteeship paradigm consciously engages with this world and tries to change and preserve it. It cannot afford to be quietist and it is no wonder, then, that Abderrahmane explicitly rejects claims that Sufism is an essentially quietist strand of mysticism (Ibid., 175).

There is another way in which the modern context affects Abderrahmane's philosophy. As was mentioned earlier, the kind of freedom that gives rise to modern anxiety is not only of the metaphysical sort, i.e. the result of a deterministic and meaningless view of nature. It also results from more concrete forms of oppression. Both the much-enlarged ability of the nation state with its powerful bureaucracy and the everyday oppression of the individual through the greater role of public opinion cause modern intellectuals to be more sensitive to issues surrounding the relation of the individual to society, like liberty, autonomy, and personal authenticity. Existentialism is exemplary in this regard, with its call for radical freedom and individual authenticity as a means to confront the tyranny of public opinion, as are Adonis's concerns for the revolutionary qualities of Sufism and his touting of the creative artist who opposes tradition.

Though Abderrahmane lacks Adonis's revolutionary vigor, he is aware of this threat. This is particularly evident when he discusses the problems associated with guided reason. Although he commends guided reason for following an Islamic moral framework, he also chides it for its tendency to breed blind imitation of authorities or tradition, as well as superficiality in performing one's religious duties. Once the individual believer himself becomes aware of the hidden meanings that have heretofore remained uncovered, he will realize the sense of what God commands and once he realizes this, he will no longer need to heed the interpretations of others to do what is right and refrain from what is forbidden. In other words, Abderrahmane recognizes the problems associated with the strained modern relationship between the individual and society. $\mathrm{He}$ feels the need for an autonomous individual who can withstand the pressures of society, and here too he thinks Sufism offers a solution. Like his contemporaries, he turns to the autonomous, authentic individual. Yet this autonomous individual is not the outcome of an existentialist's radical choice, or an act of aesthetic self-creation. Rather, he is a trustee of God who performs this role by devoting his life to a mystical practice. 


\section{Conclusion}

This chapter was written with the intention of exploring how Taha Abderrahmane's Sufi advances are not only an integral part of the Sufi tradition, but also a reaction to a modern context with its own set of problems. Be that as it may, the questions that this chapter raises go beyond this mere exegetical concern. The modern Sufism employed by Abderrahmane reserves a central role for the individual practitioner. This recognizably modern element carries with it a host of ethical, social, and political implications. After all, conceptions of the self obviously hang together with conceptions of freedom, which in turn affect the scope for social and political cooperation. What this will mean in detail for the ethics implied by Abderrahmane's philosophical project is a question that requires more detailed and extensive study. This chapter can be read as its prolegomenon. For, in order to assess the question of Abderrahmane's ethics, we first need to acknowledge the modern sensibilities that influence his ideas and allow him to speak to the moral concerns of the modern reader.

\section{References}

Abderrahmane, Taha. 1979. Langage et philosophie: essai sur les structures linguistiques de l'ontologie. Publications de la faculté des lettres et des sciences humaines-Rabat: Thèses et Mémoires.

'Abd al-Raḥmān, Ṭāha. 20og. Al-'Amal al-Dīn̄i wa-Tajdīd al-'Aql [Religious Practice and the Renewal of Reason]. 4th ed. Casablanca: al-Markaz al-Thaqāfì al-'Arabī.

'Abd al-Raḥmān, Țāha. 2013a. Al-Hiwār Ufuqan lil-Fikr [Dialogue as a Horizon for Thought]. Beirut: al-Shabka al-Arabiyya lil-Abhāth wa-l-Nashr.

'Abd al-Raḥmān, Ṭāha. 2013b. Rūh al-Hadātha: al-Madkhal ilā Ta’sīs al-Hadātha alIslamiyya [The Spirit of modernity: The Portal to the Foundation of Islamic Modernity]. 3rd ed. Beirut: al-Markaz al-Thaqāfì al-'Arabī.

'Abd al-Raḥmān, Ṭāha. 2013c. Su'āl al-Akhlāq: Musāhama fì l-Naqd al-Akhlāqi lil-Hadātha al-Gharbiyya [The Question of Ethics: A Contribution to the Ethical Critique of

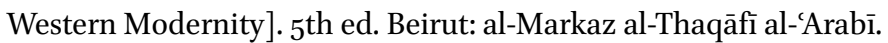

'Abd al-Raḥmān, Țāha. 2014. B’us al-Dahrāniyya: fì l-Naqd al-I'timānī li-Faṣl al-Akhlāq 'an al-Dīn [The Misery of Materialism: On the Trusteeship Critique of the Separation of Ethics from Religion]. Beirut: al-Markaz al-Thaqāfī al-'Arabī.

'Abd al-Raḥmān, Ṭāha. 2017. "Ṭāha 'Abd al-Raḥmān ... al-Faylasūf al-Mujaddid.” [Taha Abderrahmane ... The Renewing philosopher] al-Jazeera. www.youtube.com/watch ?v=oMF_mN70Q3Q\&t=440s. 
Adonis. 2013. Sufism and Surrealism. Translated by Judith Cumberbatch. (Ibook). Beirut: Saqi.

Adūnīs. 2014. Fātiḥa li-Nihāyat al-Qarn [An Opening for the End of the Century]. 3rd ed. Beirut: Dār al-Sāqī.

Adūnīs. 2016a. Al-Thābit wa-l-Mutahawwil: Baḥth fì l-Ibdā' wa-l-Ittibāc 'inda al-'Arab [The Static and the Dynamic: An Investigation into Creativity and Imitation]. Vol. 1. Cairo: al-Hay'a al-Āmma li-Quṣūr al-Thaqāfa.

Adūnīs. 2016b. Al-Thābit wa-l-Mutahawwil: Bahth fì l-Ibdā' wa-l-Ittibāc 'inda al-Arab [The Static and the Dynamic: An Investigation into Creativity and Imitation]. Vol. 2. Cairo: al-Hay'a al-'Āmma li-Quṣūr al-Thaqāfa.

Asad, Talal. 2003. Formations of the Secular: Christianity, Islam, Modernity. Stanford University Press.

Badawī, 'Abd al-Raḥmān. 1982. Al-Insānīya wa-l-Wujūdiyya fì l-Fikr al-Arabī [Humanism and Existentialism in Arab Thought]. Kuwait/Beirut: Wikālat al-Maṭbū'āt/Dār al-Qalam.

Badawī, 'Abd al-Raḥmān. 1973. Al-Zamān al-Wujū d̄̄ [Existential Time]. 3rd ed. Beirut: Dār al-Thaqāfa.

Bātțāwī, Rajā’. 2019. “Ṭaha 'Abd al-Rahmān ... Ākhir Ḥukamā’ al-Maghrib," Shabkat alRuwwād al-Thaqāfyya. Accessed June 3o. http://bit.ly/BettawiTaha.

Collingwood, Robin G. 1939. An Autobiography. Oxford: The Clarendon Press.

Di-Capua, Yoav. No Exit: Arab Existentialism, Jean-Paul Sartre, and Decolonization. Chicago: Chicago University Press, 2018.

Guignon, Charles. 2004. On Being Authentic. London: Routledge.

Hashas, Mohammed. 2015. "Taha Abderrahmane's Trusteeship Paradigm: Spiritual Modernity and the Islamic Contribution to the Formation of a Renewed Universal Civilization of Ethos." Oriente Moderno 95: 67-105.

Ibn 'Ajība, Aḥmad Ibn Muhammad. 20o6. Tafsìr al-Fātiḥa al-Kabìr [The Great Commentary of the Fātiha]. Beirut: Dār al-Kutub al-'Ilmiyya.

Kleinberg, Ethan. 2005. Generation Existential: Heidegger's Philosophy in France, 19271961. Cornell University Press.

Knysh, Alexander. 2017. Sufism: A New History of Islamic Mysticism. Princeton University Press.

Loutfy, Nour, and George Berguno. 2005. "The Existential Thoughts of the Sufis." Existential Analysis 16 (1): 144-155.

Macintyre, Alasdair. 2013. After Virtue. London: Bloomsbury.

Mashrūh, Ibrāhīm. 2009. Ṭāha 'Abd al-Rahmmān: Qirā’atun fì Mashrūihi al-Fikrī. [Taha Abderrahmane: A Reading of his Intellectual Project] Beirut: Markaz al-Haḍāra liTanmiyat al-Fikr al-Islāmī.

Murdoch, Iris. 1997. Existentialists and Mystics: Writings on Philosophy and Literature. Edited by P. Conradi. London: Chatto \& Windus. 
Schimmel, Annemarie. 1975. Mystical Dimensions of Islam. Chapel Hill: University of North Carolina Press.

Taylor, Charles. 1989. Sources of the Self. Cambridge, mA: Harvard University Press.

Taylor, Charles. 1991. The Ethics of Authenticity. Cambridge, MA: Harvard University Press. 